Article

\title{
Research on the Evolution of Building Technology Based on Regional Revitalization
}

\author{
Jingjing $\mathrm{Wu}^{*}$, Hongyang Wei and Li Peng * \\ School of Architecture and Urban Planning, Chongqing University, Chongqing 400044, China \\ * Correspondence: jingjing.2004_9@163.com (J.W.); 20151501002@cqu.edu.cn (L.P.); \\ Tel.: +86-135-9406-4963 (J.W.); +86-151-2305-1093 (L.P.)
}

Received: 23 May 2019; Accepted: 2 July 2019; Published: 8 July 2019

\begin{abstract}
With the rapid development of the times, regionalization has become one of the hotspots in the field of architecture. The aim of this paper is to deal with the regionalization of contemporary architecture from the perspective of building technology. This paper systematically and comprehensively evaluates and summarizes the development process of China's building technology, determines the key points of the evolution of building technology, and combines a large number of historical documents and historical remains to analyze the causes of the evolution of building technology, which include the natural environment, science and technology, building system and concept consciousness. Based on this, it analyses buildings in Sichuan from three aspects—building materials, structural system and construction process-and seeks for a reasonable regional development direction of building technology. Analysis results showed that greening, integration and scientific are the evolution path of building technology in the new era. Not only building technology is a necessary means of building realization, but also its influence on the regionalization of architecture should be supplemented and promoted.
\end{abstract}

Keywords: influence factors; building materials; structural system; construction process

\section{Introduction}

Rheology, which comes from the field of material mechanics, focuses on the law of deformation and flow between materials and time. The same is true of the development of building technology. Ludwig Mies Van der Rohe once said, "technology is rooted in the past, dominates the present and extends to the future" [1]. It is known that building technology is constantly developing and innovating in the time dimension, and will not stop or disappear. Before the industrial revolution, China's building technology was dominated by soil-wood structures, while Western building technology was dominated by stone-wood structures. In essence, the two were consistent and belonged to natural materials. After the industrial revolution, the emergence of artificial materials such as steel, glass, concrete, etc. brought new structural forms [2], such as steel structures and reinforced concrete structures, and the emergence of mechanized production tools also brought new construction processes [3]. At the same time, the popularity of electricity, insulation materials [4] and the widespread use of modern construction equipment [5] had contributed to the development of environmental control technologies [6].

In the past, building technology was created based on a specific geographical environment. Nowadays, with the rapid development of technology and information, modern technology has almost ablated the geographical concept of time and space, resulting in the convergence of architecture $[7,8]$. However, convergence is relative to difference, especially regional differences. If regional differences exist, convergence is always relative [9]. Therefore, the regional nature of building technology is the key to solving the problem. 
Regionality began with the concept of regionalism mentioned by Lewis Mumford in 1924 [10], and led to a series of discussions. Among them, Giedion thought that new regionalism had special significance for third world countries [11]. Erskine explained regionalism from a human and geographical perspective [12]. Norberg Schultz more fully integrated regionalism into architecture [13]. Alexander Tzonis and Liana Lefevre explicitly proposed critical regionalism and used locality to resist the impact of global civilization [14]. Critical regionalism also emphasizes the influence of regional factors on the development of architecture. Although China's studies on regionality emerged later than abroad, most of them focus on architecture, culture and image [15-17], with less emphasis on building technology. Therefore, the purpose of this paper is to analyze the development of China's building technology, determine the causes of its evolution, and find a feasible path of contemporary building technology, in order to achieve the purpose of regional revitalization.

\section{Historic Evolution}

Building technology is accompanied by the emergence of buildings, and a complete history of building technology carries the entire development of the building. Building structure is the main element of building technology, and it can be used to trace the history of building technology. According to records, building structure has existed since the beginning of human civilization and has been influenced on many aspects such as economy, politics, science and technology, and culture. It is mainly divided into the following stages (Figure 1):

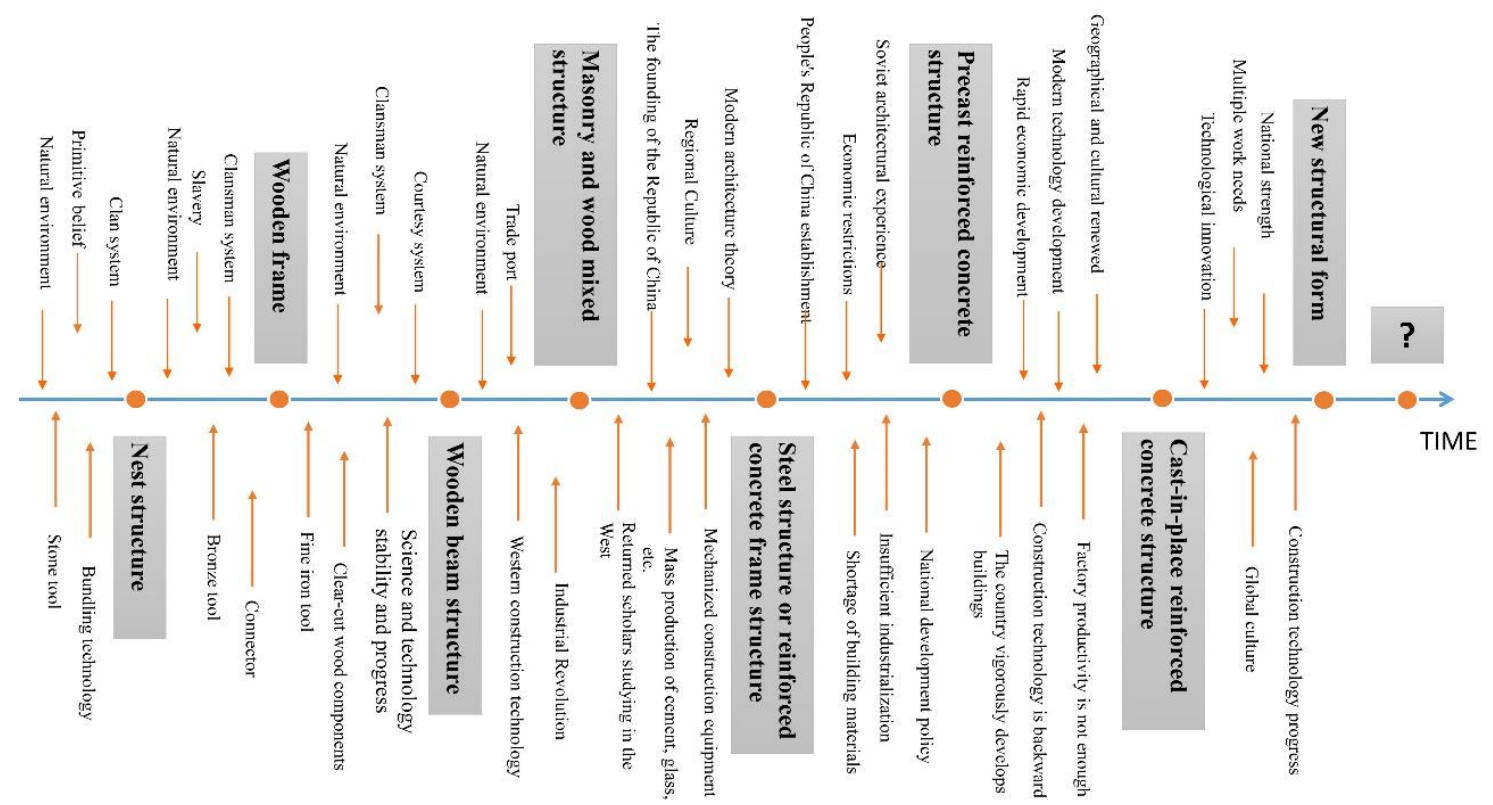

Figure 1. Time diagram of the development of building technology.

Nest structure. Ancestors began with the structure of the nest in primitive society (about 1.7 million years ago to around 21st century BC). With the rich experience of labor, ancestors gradually moved to ground buildings and dry-column buildings. The emergence of bauxite, dark foundation and Qingyan column was crucial to the development of the building. The nest structure is the source of the soil-wood structure.

Wooden frame structure. In slave society (around 21st century BC to around 2nd century BC), the concentration of rights and the emergence of bronze tools had promoted the development of the wooden frame structure and the plate-building method.

Wooden beam structure. Due to the stability of economy and culture in feudal society (around 2nd century BC to late 18th century), craftsmen used their experience and lessons learned from practice and 
gradually formed a whole set of building technologies on a wooden beam structure, which included structural components, such as the foundation, the wall, the roof and the arch.

Brick (stone)-wood mixed structure. After the Opium War in 1840, the trading ports were established, and a large number of Western building techniques were introduced. Then, a brick (wood) load-bearing structure with wooden trusses and iron roofs appeared. However, most buildings still used a wooden beam structure, because the new alternative was too expensive.

Steel structure or reinforced concrete structure. During the Republic of China (1912-1949), many Western architects and Chinese overseas architects poured into the Chinese construction market and established several architectural firms. In the same period, the construction level of construction workers had gradually matured. Together these provided a solid human foundation for the development of concrete structures. After the opening, many steel, cement, glass and other factories, and semi-mechanical construction tools provided a material basis. Additionally, under the strong promotion of the government, the development of steel structure and reinforced concrete structure was promoted. At the same time, the wood structure from the historical stage gradually faded in use [18].

Precast reinforced concrete structure. New China was founded in 1949. Due to political and economic factors, the government directly drew on Soviet building technology experience. To save steel and cement, industrial buildings widely promoted prestressed precast reinforced concrete structure. Houses still were dominated by the brick-concrete structure in the same period.

Cast-in-place reinforced concrete structure. Until the reform and opening up in 1978, the output of the prefabricated structure and the construction technology of the workers could not meet the needs of the society due to the increase in construction volume. The cast-in-place concrete structure came into being, greatly improving building safety and construction speed.

New structural form. Since 2000, in the era of technological innovation, the building structure has created a lot of forms, such as grid structure, thin shell structure, suspension structure and aerated structure to satisfy super high-rise buildings, large-span buildings and super-large-scale buildings.

\section{Exploring the Evolution Factors of Building Technology}

The Great Learning said, "if you can one day renovate yourself, do so from day to day, and let there be daily renovation". The general idea is to look at the development of things from a dynamic and introspective point of view, and building technology should also be like this. Building technology is a very complex system, including building materials and structures, building physics and equipment, construction and many other aspects. It is also necessary to sort out the development of building technology dynamically and systematically. Therefore, this paper aims to explore the evolutionary laws from the following aspects and guide the development of contemporary building technology.

\subsection{Basic Factors: Natural Environment}

Building technology exists to provide human beings with a physical and spiritual 'shelter'. Its essence lies in directly and simply solving the contradiction between man and nature. It can be said that building technology will vary with the geographical conditions of the climate. There are seven architectural climate zones in China, and different zones form different building technologies (see Figure 2). Cold and warmth are considered in hot and cold areas. Both heat protection and cold protection are required in hot summer and cold winter areas. Summer heat and winter warm areas are concerned with ventilation and heat insulation, while mild areas pay more attention to ventilation. It can be seen that climate adaptation becomes one of the keys of building technology [19]. In addition, the structure of buildings is mostly dry-column buildings in the ancient mountainous and hilly areas of China, while the plains and basins are mostly buildings. Therefore, traditional building technology is the result of natural selection of the survival of the fittest, and the natural environment is the basic factor for the evolution of building technology. 

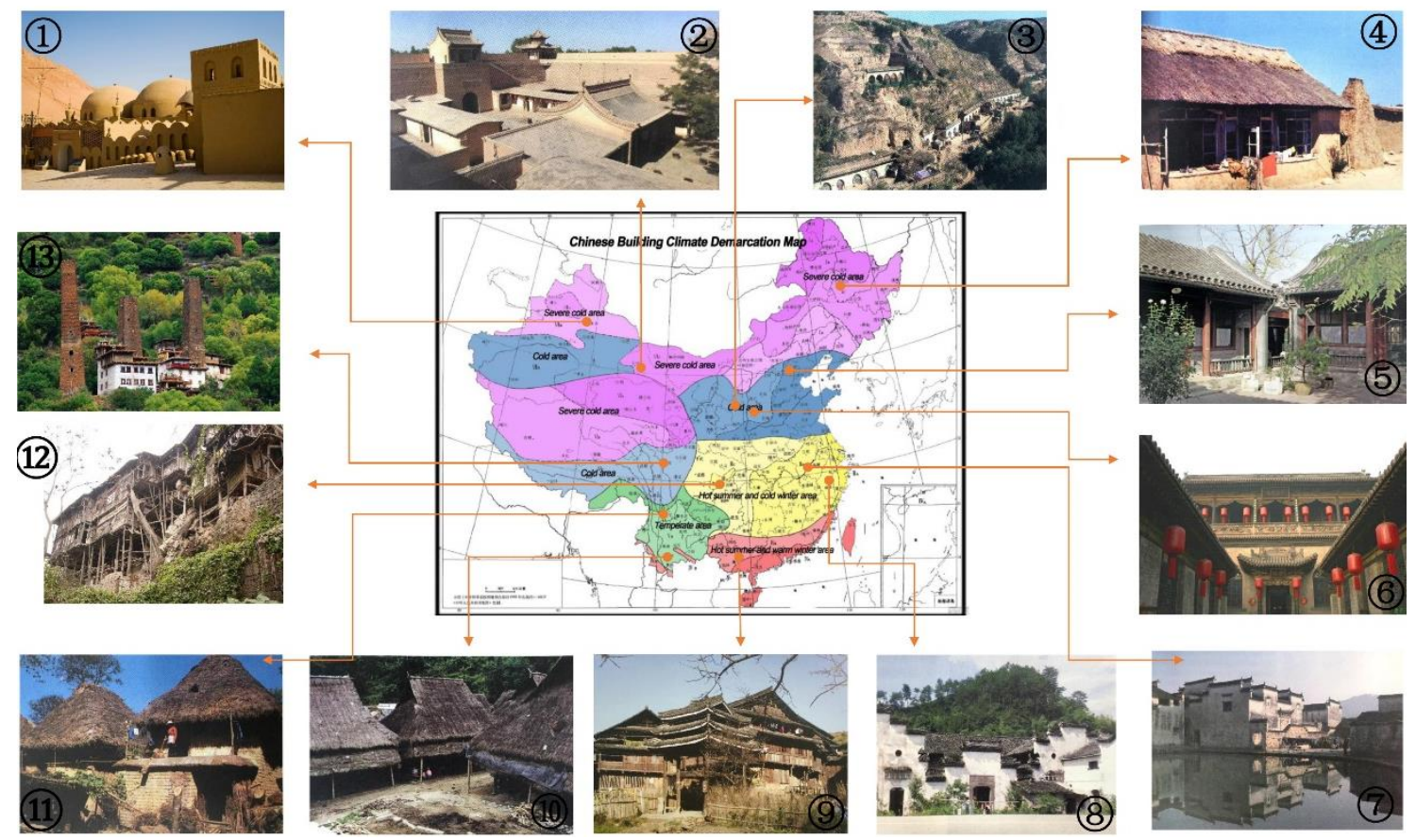

Figure 2. Chinese traditional architecture map.

Since the industrial revolution, modern technology had transcended the limitations of nature and began to blindly transform the living environment of mankind, causing great destruction of ecology. Therefore, the development of contemporary building technology needs to consider the role of the natural environment, extract 'effective genes' from traditional technologies, rationally use the 'accumulation effect' of technology, create building technologies that adapt to different climatic conditions, and improve the ecological environment.

\subsection{Promoting Factors: Science and Technology}

Science and technology are the driving force behind the development of building technology, and every stage of technological development is closely related to the renewal of building tools. It can be seen from Table 1 that from stone tools to bronze tools to iron tools, the ancestors had done their best in the application of wood coupled with the continuous, stable and slow growth of China's science and technology. Finally, they formed a set of wooden beam structures as the main frame. In modern times, the industrial revolution led to artificial construction materials and mechanization of the construction process, which largely expanded the scale and complexity of the buildings. So, the advancement of science and technology has brought an opportunity for the innovation of building technology.

No matter what form or in which field, technology has developed from low to high and from simple to complex, and it has risen and fallen [20]. There is always a spiral response to the development of technology. Building technology may lose geographical support if it is followed blindly. For example, air conditioning solves the indoor comfort level, but the result is the heat island effect. Thus, air conditioning is required more frequently. Today, traditional technology has been re-enabled in the ecological crisis. Therefore, it is necessary to correctly treat the promotion of science and technology to building technology. Do not blindly admire modern technology or ignore traditional technology. It is important to choose appropriate construction techniques. 
Table 1. Comparison of construction tools and building structures in various historical stages.

\begin{tabular}{|c|c|c|c|}
\hline Historical Period & Construction Tools & Structure Type & Icon \\
\hline Primitive society & $\begin{array}{l}\text { From chopping stone tools to } \\
\text { polishing stone tools, wood, bone, } \\
\text { pottery and other tools. }\end{array}$ & Nest structure & \\
\hline Slave society & $\begin{array}{l}\text { Bronze tool, knives, axes, saws, } \\
\text { chisels, drills and other sharp wooden } \\
\text { tools }\end{array}$ & Wooden frame structure & \\
\hline Feudal society & $\begin{array}{l}\text { Iron tool, tools for felling and } \\
\text { unwinding, such as axe, saws and } \\
\text { frame saws }\end{array}$ & Wooden beam structure & \\
\hline Republic of China & $\begin{array}{l}\text { Handmade gradually is replaced by } \\
\text { mechanical construction: } \\
\text { Development of building materials } \\
\text { industry such as brick, glass and } \\
\text { wood processing;Introduction of new } \\
\text { equipment such as air conditioners } \\
\text { and elevators }\end{array}$ & $\begin{array}{l}\text { Brick (stone) wood mixed } \\
\text { structure; } \\
\text { Brick (stone) reinforced } \\
\text { concrete structure; } \\
\text { Steel structure or reinforced } \\
\text { concrete structure }\end{array}$ & \\
\hline Early founding & $\begin{array}{l}\text { The mechanization and assembly } \\
\text { degree of the construction are } \\
\text { improved; } \\
\text { The flow operation method and the } \\
\text { winter construction method }\end{array}$ & $\begin{array}{l}\text { Precast reinforced concrete } \\
\text { structure }\end{array}$ & \\
\hline $\begin{array}{l}\text { After the reform } \\
\text { and opening up }\end{array}$ & $\begin{array}{l}\text { Introduction of computer-aided } \\
\text { technology; } \\
\text { Mechanization of building } \\
\text { construction; } \\
\text { Diversification and intelligentization } \\
\text { of construction equipment }\end{array}$ & $\begin{array}{l}\text { Cast-in-place reinforced } \\
\text { concrete structure }\end{array}$ & \\
\hline
\end{tabular}

\subsection{Constraints Factors: Building System}

The building system is a set of laws and regulations involved in construction activities that must be observed by all parties [21]. Starting from the clan society, building technology was influenced by the clan system and the ritual and music hierarchy system, and gradually formed a set of officially specific architectural concepts and corresponding systems and regulations that constrained the form, scale and layout of the building [22]. The hierarchy system regulated the development of buildings 
and cities more harmoniously and orderly and played a certain role in the production of out-of-control construction. It also limited the development of ancient buildings and technological innovation.

This hierarchy ended and the Western building system was introduced in the Republic of China. It still did not form its own building system in the early days of the founding of the People's Republic of China, not yet fully adopting the Western and Soviet building system. The building system with Chinese characteristics began to develop and improve after reform and opening up.

Table 2 shows that the evolution of building technology has always been restricted by the building system. Although the initial development of the system is conducive to the summarization and application of technology, it constrains and restricts the development and innovation of technology in the later stage of the system. Therefore, the development of building technology and building systems need to advance, integrate and innovate with each other, leaving a certain flexibility space for each other, alleviating the contradiction between advantages and disadvantages, and better promoting the benign development of the two.

Table 2. Relevant contents about building technology in each historical period.

\begin{tabular}{|c|c|c|c|}
\hline Historical Period & Construction Participant & Building System & Related to Building Technology \\
\hline Primitive society & Everyone & Clan system & $\begin{array}{l}\text { At that time, there was no clear } \\
\text { norm, only to meet the needs of } \\
\text { living and production in groups and } \\
\text { to express religious beliefs. }\end{array}$ \\
\hline Slave society & Slave & Separate system & $\begin{array}{l}\text { Through the bloodline clan system, } \\
\text { a strict hierarchy of superiority and } \\
\text { subordination is created to make } \\
\text { people stand in their own right, and } \\
\text { architecture is no exception. }\end{array}$ \\
\hline Feudal society & $\begin{array}{l}\text { Management and construction } \\
\text { of the industrial officer; } \\
\text { Folk craftsman }\end{array}$ & $\begin{array}{l}\text { The hierarchy of ethics } \\
\text { and rituals }\end{array}$ & $\begin{array}{l}\text { Determine the combination of the } \\
\text { building regulations and the } \\
\text { hierarchy of the city and the palace, } \\
\text { the form, scale, layout, materials } \\
\text { and decoration of the house, and } \\
\text { gradually form the official } \\
\text { construction laws and regulations. } \\
\text { Building regulations pay more }\end{array}$ \\
\hline Republic of China & $\begin{array}{l}\text { National Government } \\
\text { Construction Committee; } \\
\text { Private architecture firm; } \\
\text { Private construction enterprise }\end{array}$ & $\begin{array}{l}\text { Western architectural } \\
\text { system adapted to } \\
\text { industrial conditions } \\
\text { Building Law, etc. }\end{array}$ & $\begin{array}{l}\text { attention to design, guide national } \\
\text { construction, promote "inherent } \\
\text { forms of China" and have detailed } \\
\text { regulations on public housing, } \\
\text { schools, and industries. }\end{array}$ \\
\hline Early founding & $\begin{array}{l}\text { Construction Engineering } \\
\text { Department; State } \\
\text { Construction Company; } \\
\text { Central Design Institute, } \\
\text { Soviet expert }\end{array}$ & $\begin{array}{l}\text { Basically, quote the } \\
\text { existing Soviet building } \\
\text { system to meet the } \\
\text { construction } \\
\text { requirements at that time; } \\
\text { Design Work } \\
\text { Regulations, etc.; }\end{array}$ & $\begin{array}{l}\text { The government can only control } \\
\text { the construction work in a macro } \\
\text { manner, lack of plans and } \\
\text { regulations, and building standards } \\
\text { are not high. Design principles are } \\
\text { based on "applicability, economy, } \\
\text { and attention to beauty under } \\
\text { possible conditions". }\end{array}$ \\
\hline $\begin{array}{l}\text { During the Cultural } \\
\text { Revolution }\end{array}$ & $\begin{array}{l}\text { Construction Engineering } \\
\text { Department; State } \\
\text { Construction Company; } \\
\text { Architectural Design Institute } \\
\text { of the Ministry of Construction }\end{array}$ & Design revolution & $\begin{array}{l}\text { From design ideas to design content } \\
\text { and design methods, from technical } \\
\text { theory to technical norms, } \\
\text { management systems embody } \\
\text { political, regional, domain and } \\
\text { internal modernity. }\end{array}$ \\
\hline $\begin{array}{l}\text { Reform and opening } \\
\text { up period }\end{array}$ & $\begin{array}{l}\text { Ministry of Construction; } \\
\text { state-owned and private } \\
\text { construction companies; } \\
\text { state-owned and private } \\
\text { architectural design institutes }\end{array}$ & $\begin{array}{l}\text { Various laws and } \\
\text { regulations related to } \\
\text { building and planning to } \\
\text { adapt to national } \\
\text { conditions, etc. }\end{array}$ & $\begin{array}{l}\text { Building policy of "appropriate, } \\
\text { safe, economical and beautiful" } \\
\text { Implementation of a registered } \\
\text { architect system }\end{array}$ \\
\hline
\end{tabular}

\subsection{Potential Factors: Conceptual Awareness}

An important reason why humans are different from other animals is that people are subjective. From the original Paleolithic beliefs of the Paleolithic Age to the Sun beliefs of the Neolithic Age to the various religious beliefs, they were all embodied in architecture and thus achieved through building 
technology. According to dialectical materialism, there is a decisive consciousness: consciousness actively reacts to existence, and this reaction is decisive for the development of things.

Therefore, building technology is influenced by values, philosophy, religion, aesthetics, and all conscious activities used to regulate and guide architectural activities. Among them, values are the fundamental conscious values that guide people's thoughts and behaviors [23]. China's traditional values are dominated by the practical rational spirit [24] and have the relevant tool rationality of practicality and effectiveness. It fundamentally reflects the essence of building technology, which has an emphasis on practicality and neglect of experimentation. Taking the traditional tenon and mortise structure as an example (Figure 3), to maximize utility, the ancients only used the simple occlusion of the gimmick protruding from the component itself and the squint of the sag to complete the connection between the components and then derived the ever-changing combination. Practical rationality makes traditional technology pay attention to practicality, but it also has the shortcomings of short-sightedness.

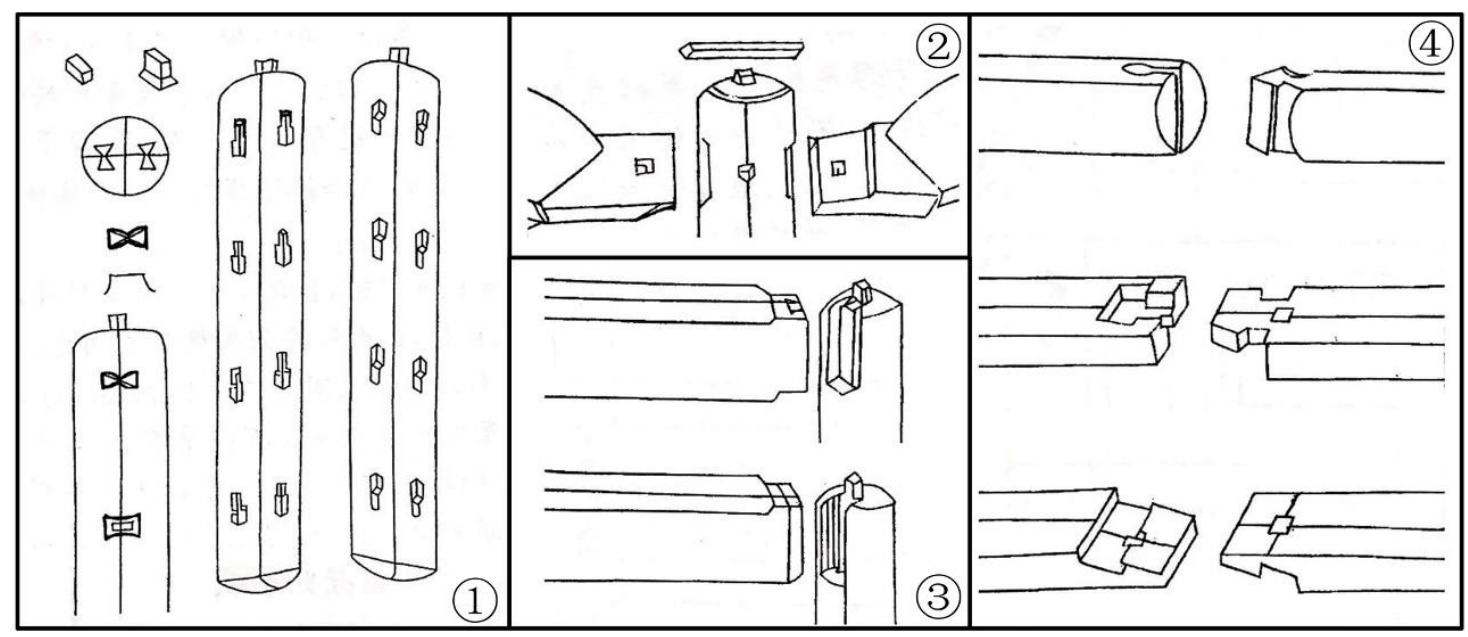

Figure 3. Schematic diagram of parts of tenon and mortise structure in Rules of Architecture.

After the Opium War, Western civilization intruded, and Chinese society gradually began to reflect on the gains and losses of traditional values. Our traditional values gradually disintegrated, and new values began to wage a conflict between Western values and traditional values. The same is true of building technology. The big roof building in the Republic of China is the best example. Modern technology prevailed until the advent of globalization, as did the values. But the concept of consciousness always lags behind and subtly influences the evolution of building technology.

Today, for the Chinese dream, we should cultivate and promote the core values of socialism [25]. Building socialist core values requires the achievement of outstanding genes that inherit traditional values while innovating and developing the values of the new era. Therefore, building technology must not only absorb the essence of traditional technology, but also actively respond to the spirit of the times, and construct building technology with Chinese characteristics.

In summary, building technology is influenced by factors such as the natural environment, science and technology, building system, and conceptual awareness. These factors promote or inhibit the development of building technology at different stages. From a dynamic and holistic perspective, building technology is innovating and moving forward in a spiral way. Therefore, after fully understanding the influencing factors of the evolution of building technology, we can ensure stable, healthy and orderly development.

\section{Evolution Paths: The Development Direction of Building Technology in Sichuan}

The evolutionary causes of building technology affect its developmental direction. The development of building technology involves the localization problem, and also the sustainable 
development problem [26]. Building technology also includes all technical means, which is roughly divided into three aspects: building materials, structural systems and construction process [27]. Because the soil-wood structure is the source in China, this paper attempts to find a feasible evolutionary path by taking the Sichuan region as an example.

\subsection{Greening of Building Materials}

From the agricultural society to the industrial society to post-industrial society, the innovation of building materials always promotes the innovation of structural systems and construction process. Building materials are the primary factor in the development of building technology [28]. In the pursuit of green buildings, the greening of building materials will be an inevitable trend. This requires that building materials have the least impact on the ecological environment during the whole lifecycle through production, use and disposal, in order to achieve commonalities such as safety, energy conservation, environmental protection and recycling [29]. The eight aspects of the Green Building Evaluation Standards all involve the greening of building materials (see Figure 4).

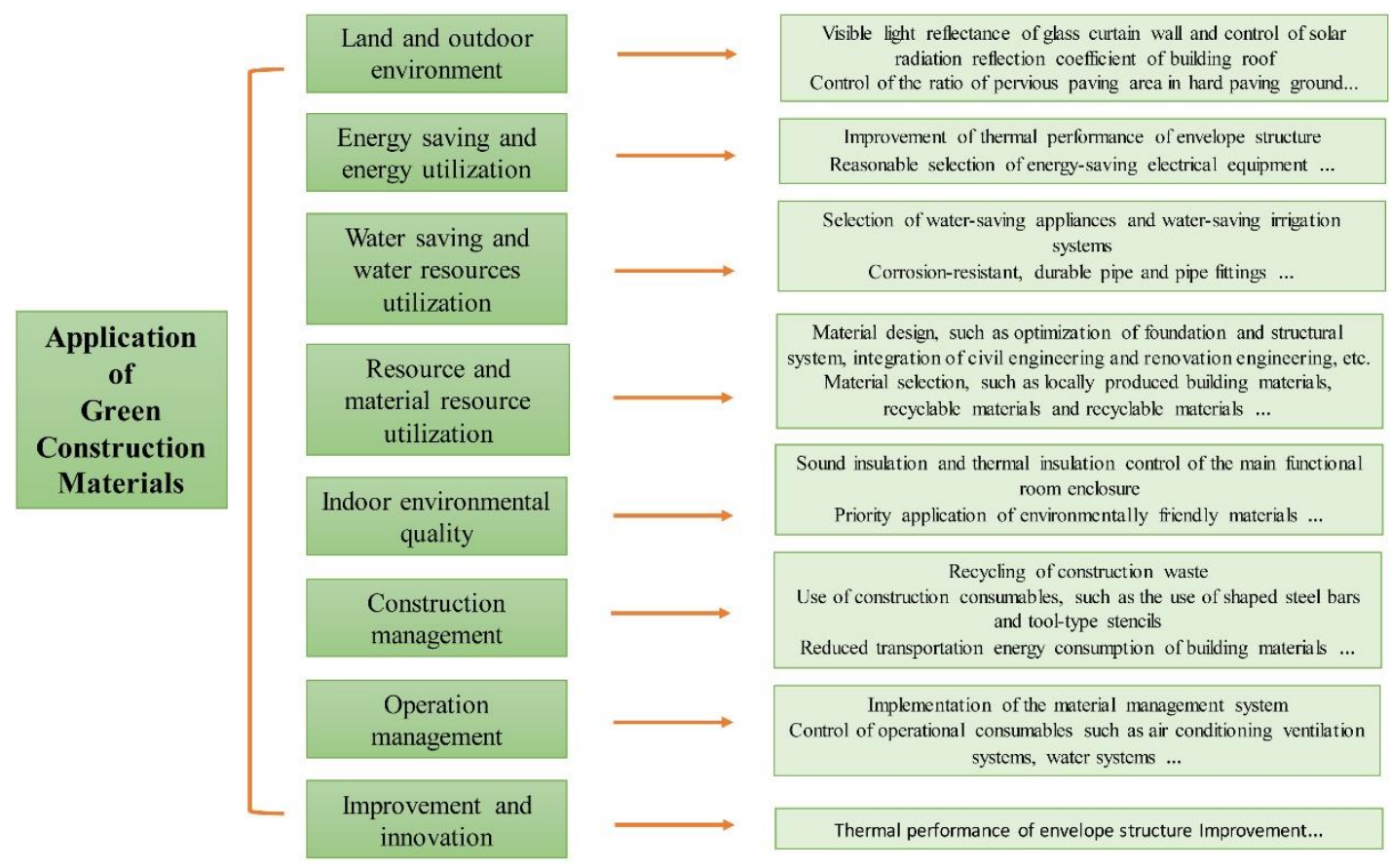

Figure 4. Application of green building materials in Green Building Evaluation Standards.

Sichuan has abundant sunshine and concentrated rainwater. Tree resources are abundant. Additionally, the philosophy of harmony between man and nature conforms to the development of local wood. Modern wood not only has good ecological properties, but also better mechanical properties, thermal insulation properties, fire protection, moisture resistance and shock resistance than natural wood, which together meet the problem of sustainable development of buildings. There are many cases of modern wood in Sichuan, such as antique tourist buildings that satisfy emotional needs, Wenchuan disaster buildings that meet seismic needs, and residential buildings that meet ecological needs (Figure 5). 

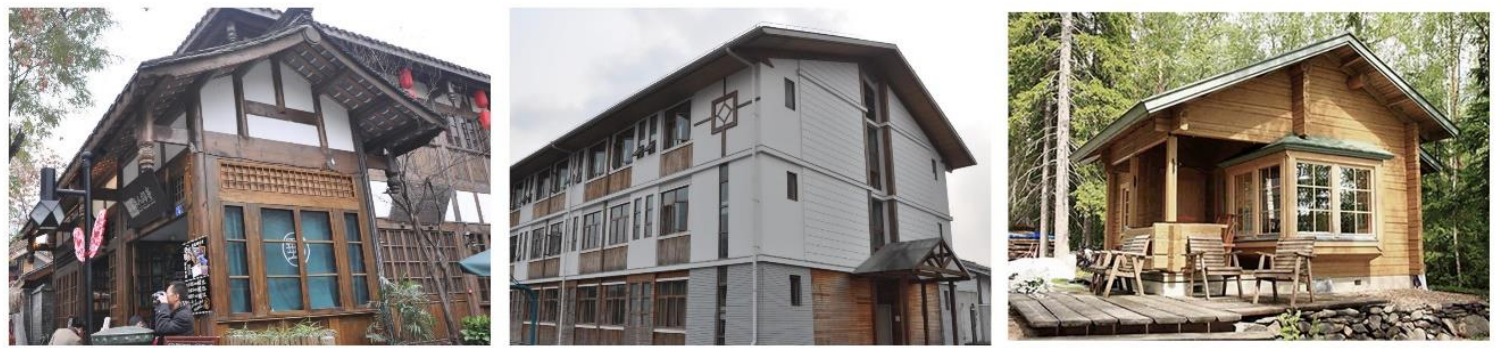

Figure 5. Applications of green building materials in Sichuan.

\subsection{Integration of Structural Systems}

The wooden beam-column system is the essence of traditional buildings. Lin once affirmed the traditional structural spirit and pointed out the intersection of modern architecture and traditional architecture, in order to provide a theoretical point of developing the modern structure [30]. Subsequent structural systems have shown structure spirit, but there are more or less deficiencies in the overall.

Under the emergence of prefabricated building, this situation is reversed. From the perspective of generative logic, the wooden beam-column structure in Sichuan is a combination of carpentry work and joinery work. Prefabricated building is coordinated to create an efficient organic whole from the design, from the production to the on-site construction [31]. It can be seen from the flow chart (Figure 6) of the two constructions that the prefabricated building can be regarded as an extension and evolution of the wooden beam-column system, which is a reasonable development direction for the integration of structural systems. It not only meets the inheritance of traditional wood structure system, but also caters to the development of modern technology.

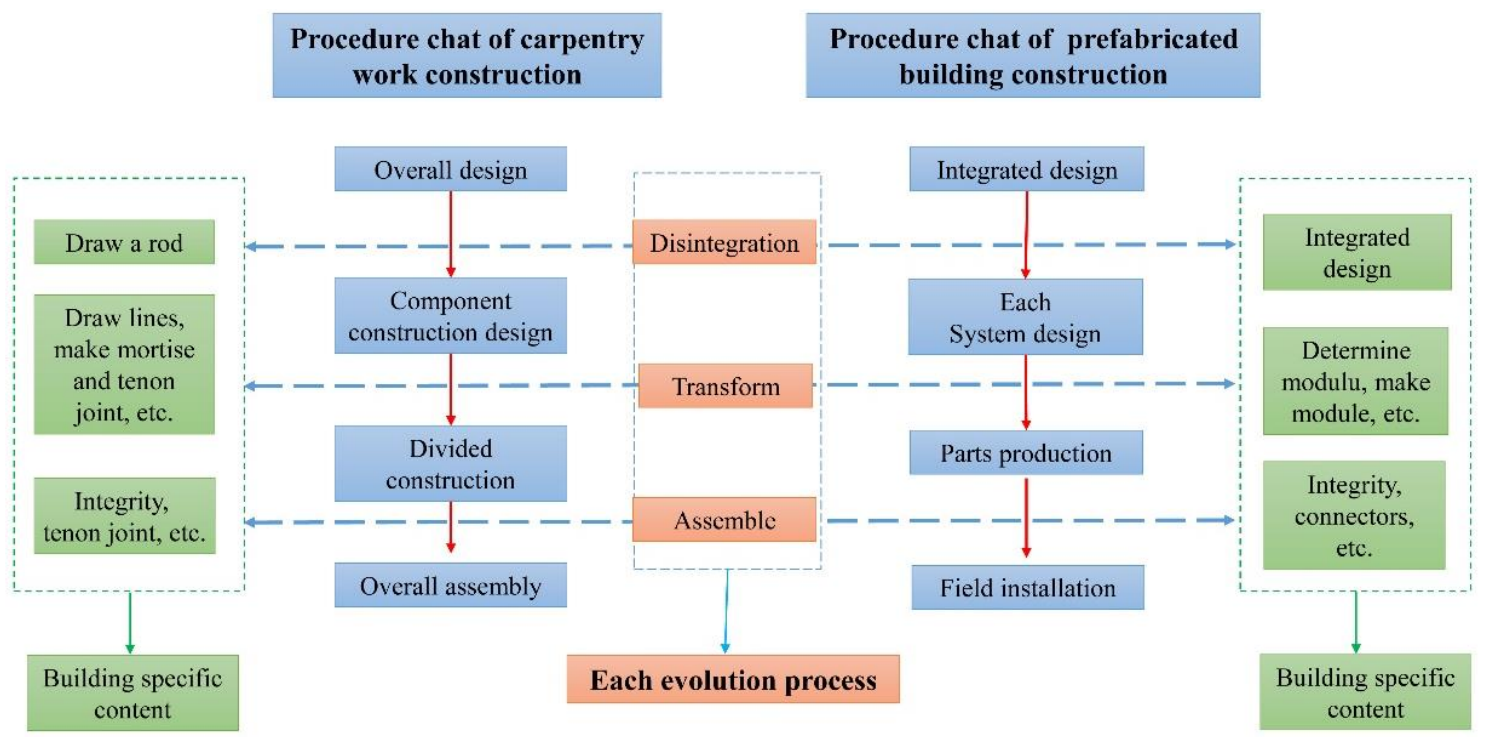

Figure 6. Procedure charts of carpentry work construction and prefabricated building construction.

\subsection{Scientific Construction Process}

The traditional construction process has always been taught by masters and apprentices, which is restricted by regional factors and human factors. The process is the result of continuous experience and mistakes. With the advent of the industrial age, the craftsman model was gradually replaced by factory production. The construction process is always closely related to the development of building tools. Additionally, the development of science and technology has promoted the construction process to become more scientific, from the material ratio to the determination of the structural form and the mechanization of the construction tools, and it has become more detailed and specialized. 
The traditional earthen process has good ecological properties, but also poor durability and mechanical properties $[32,33]$. However, the modern earthen process is different, which improves the mechanical properties and durability through the introduction of earthen raw materials and mechanical boring tools [34,35]. The post-disaster reconstruction project in Ma'anqiao Village, Sichuan (Figure 7) is an excellent example of this [36,37]. Based on local earthen process, it systematically, comprehensively and scientifically uses various methods, such as experimental comparisons, computer simulation and physical models in soil materials, structural joints and structural systems, building physics, construction tools and construction methods. This process improves the thermal comfort of the living room as much as possible.
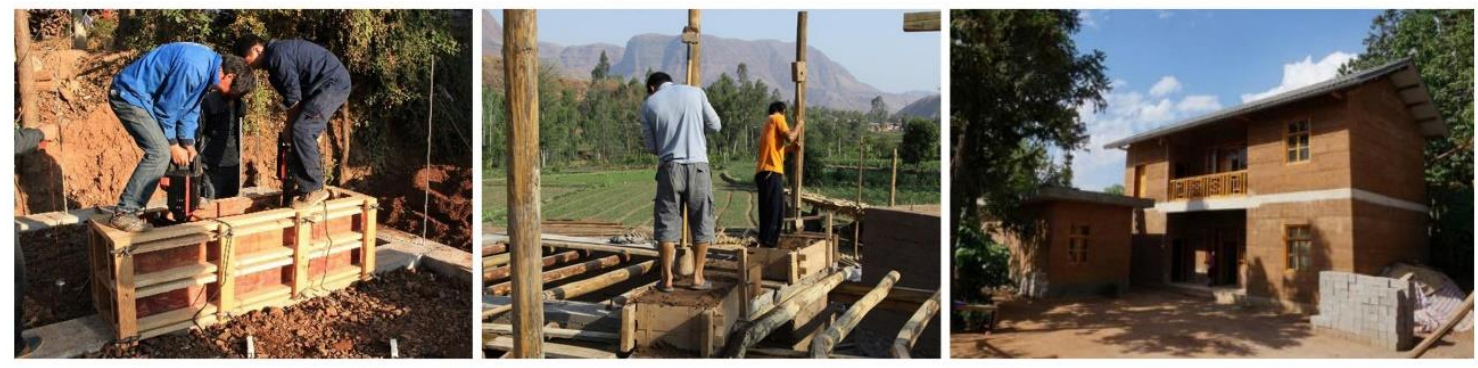

Figure 7. The reconstruction of Ma'anqiao Village in Sichuan Province takes advantage of the improved traditional rammed earth technique.

\section{Conclusions}

There is a need for different angles with which to study the evolution of building technology. Existing studies focus on the single factor of building technology, such as materials, without overall and comprehensive consideration. Thus, it is necessary to explore the influence of regional factors on the evolution of architectural technology from a more comprehensive and macroscopic perspective. This is inseparable from a large number of historical documents and practical case analysis and induction. This paper combines the existing factors of natural environment and science and technology to acknowledge their support and promotion of building technology. However, for the sudden changes that cannot be explained by traditional studies, the consideration of building system and concept consciousness is increased, which can more accurately and reasonably evaluate the evolution of building technology.

The evolution of building technology varies from region to region. Taking Sichuan as an example, the unique regional environment, human history and contemporary background have created the development of contemporary regional building technology. Compared with traditional methods that only consider the objective factors of building technology, this method is more rigorous and reliable.

Author Contributions: Conceptualization, Methodology, J.W., H.W.; Investigation, J.W., L.P.; Manuscript preparation and writing, J.W.

Funding: This research was funded by National Key Research and Development Program of China, grant number 2017YFC0702404-03.

Conflicts of Interest: The authors declare no conflict of interest.

\section{References}

1. Wu, H.J. Modern Western Architecture, 1st ed.; China Building Industry Press: Beijing, China, 1997.

2. Pevsner, N. Pioneers of Modern Design: From William Morris to Walter Gropius; Penguin Books Ltd.: London, UK, 1991.

3. Benevolo, L. Space, History of Modern Architecture; Routledge \& Kegan Paul Ltd.: Abingdon, UK, 1971.

4. Moe, K. Insulating Modernism: Isolated and Non-Isolated Thermodynamics in Architecture; Birkhauser Verlag AG: Basel, Switzerland, 2014.

5. Frampton, K. Modern Architecture: A Critical History, 4th ed.; Thames and Hudson Ltd: London, UK, 2007. 
6. Banham, R. The Architecture of the Well-Tempered Environment; The University of Chicago Press: Chicago, IL, USA, 1969.

7. Wang, Y. Thinking on globalization of contemporary architecture. New Archit. 2001, 5, 65-67.

8. Wang, Q. The modern regional architecture development under the background of globalization. J. Jilin Inst. Archit. Civ. Eng. 2012, 2, 63-66.

9. Xu, Q.L. Globalization and localization: A problem of "Modernity". Architect 2004, 3, 68-75.

10. Wu, L.Y. Architecture culture and regional architecture. Hua Zhong Archit. 1997, 2, 13-17.

11. Giedion, S. Architecture, You and Me-the Diary of a Development; Harvard University Press: Cambridge, MA, USA, 1958.

12. Klotz, H. The History of Postmodern Architecture; The MIT Press: Cambridge, MA, USA; London, UK, 1988.

13. Schulz, C.N. Roots of Modern Architecture; A.D.A. EDITA Tokyo Co., Ltd.: Tokyo, Japan, 1988.

14. Alexander Tzonis, L.L. The Grid and the Pathway. Archit. Greece 1981, 15, 175-178.

15. Li, L.; Yang, H.Z. An analysis of regional culture inheritance in commercial pedestrian streets of new urban areas: A case study. International. J. Simul. Syst. Sci. Technol. 2016, 17, 191-195.

16. Lu, F.; Li, J. Integrated interpretation on regionality research of contemporary architecture. Urban. Archit. 2008, 6, 7-8.

17. Zhang, Z.Q. Suitable expression for regional architecture. Chin. Overseas Archit. 2009, 8, 59-60.

18. Zou, D.N.; Dai, L.; Zhang, X.W. The History of Modern Chinese Architecture, 1st ed.; China Building Industry Press: Beijing, China, 2010.

19. Allen, K. Climate adaptation engineering: A new direction for environmental science, engineering and technology in urban environments. Int. J. Sustain. Dev. World Ecol. 2011, 18, 201-209.

20. Chen, C.S. Introduction to Technical Philosophy, 1st ed.; Science Press: Beijing, China, 1992.

21. Zou, D.N. A call for modernity of the architectural legal system. Time Archit. 2015, 5, 46-47.

22. Fu, X.N. The Influence of Social and Cultural Factors on the Form and Development of Ancient Chinese Architecture, 1st ed.; China Building Industry Press: Beijing, China, 2015.

23. Han, Z. Five Core Socialist Values, 1st ed.; People's Publishing House: Beijing, China, 2012.

24. Chen, B.G. Theoretical studies on traditional values nourishing socialist core values. Theor. Investig. 2016, 4, 31-36.

25. Tian, H.J.; Zou, W. The Outline of Socialist Core Values, 1st ed.; People's Publishing House: Beijing, China, 2009.

26. Pramod, P. Sustainable development and systems thinking: A case study of a heritage city. Int. J. Sustain. Dev. World Ecol. 2005, 12, 213-220.

27. Chu, D.Z. From 'Teculture' to 'Sustainability': An attitude towards architecture based on technological philosophy's view. New Archit. 2013, 5, 16-22.

28. Tulay, E. A study regarding the environmental impact analysis of the building materials production process. Build. Environ. 2007, 42, 3860-3871. (In Turkey)

29. Meng, Q.L.; Wang, S.X. Reasonable design of green building technology. Architect 2015, 2, 9-11.

30. Liang, S.C. Qing Structural Regulations, 1st ed.; China Building Industry Press: Beijing, China, 1981.

31. Chen, A.Y.; Zhang, Z.Y.; Wang, H.; Zhang, D.K.; Zhang, J.Q.; Yang, Z.Y. Construction industrialization and green module building. Build. Struct. 2013, 10, 334-336.

32. Hammond, G.P.; Jones, C.I. Embodied energy and carbon in construction materials. Energy 2008, 161, 87-98. [CrossRef]

33. $\mathrm{Mu}, \mathrm{J}$. Exploring, renewing and inheriting the tradition of earthen construction. Archit. J. 2016, 4, 1-7.

34. Elizabeth, L.; Adams, C. Alternative Construction: Contemporary Natural Building Methods, 1st ed.; Wu, C.Y., Ed.; China Machine Press: Beijing, China, 2005.

35. Li, Z.H.; Zhou, M.Q.; Chen, W.K.; Ciancio, D. Experimental investigation on in-plane shear behavior of reinforced rammed earth panels. J. Cent. South Univ. Sci. Technol. 2016, 8, 2835-2841. 
36. Wan, L.; Wu, E.R.; Mu, J. Assessment of indoor thermal environment in rural area of southwest China and optimization design: Taking post-quake rebuild projects of Ma'anqiao village for example. J. Civ. Archit. Environ. Eng. 2011, 6, 117-120.

37. Mu, J.; Zhou, T.G.; Wang, L.; Wu, E.R.; Ma, J.; Yang, H. Best way is to improve local construction study on Ma'anqiao village's reconstruction after earthquake in Liangshan of Sichuan. Archit. J. 2013, 12, 10-15.

(C) 2019 by the authors. Licensee MDPI, Basel, Switzerland. This article is an open access article distributed under the terms and conditions of the Creative Commons Attribution (CC BY) license (http://creativecommons.org/licenses/by/4.0/). 